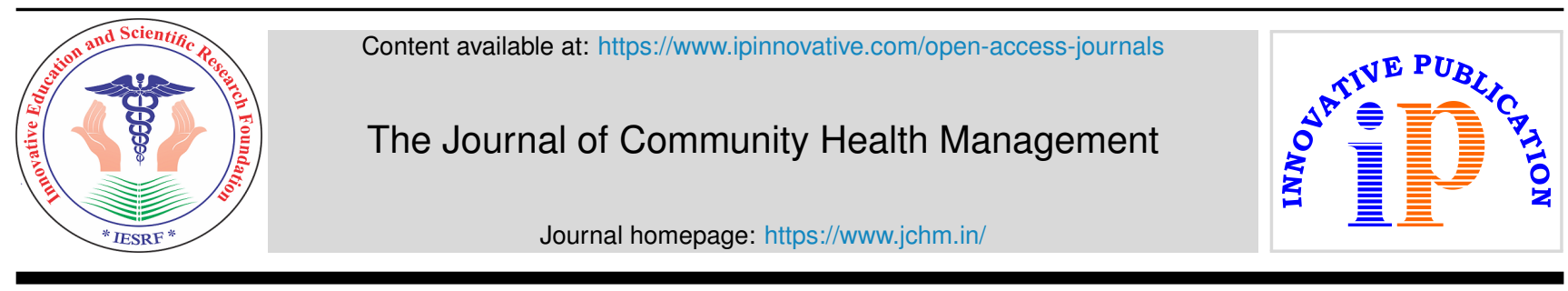

\title{
Editorial
}

\section{Unfolding the COVID-19 second wave in India}

\author{
Sheikh Mohd Saleem ${ }^{1}$ ** \\ ${ }^{1}$ Independent Public Health Researcher, Jammu and Kashmir, India
}

\section{A R T I C L E I N F O}

Article history:

Received 25-09-2021

Accepted 30-09-2021

Available online 16-10-2021

\section{Keywords:}

Covid19

Health care

leadership

\begin{abstract}
A B S T R A C T
Early efforts to vaccinate the Indian population were started on 16th January 2021. With this, a ray of hope came as people again starting their livelihoods, roads looked busy again, playgrounds were again full of children. Everything seems back to normal, while the Government was allowing all other activities with the option to follow the COVID appropriate behavior (CAB) keeping a blind eye to whether or not someone follows it. The immediate consequence of this laxity was that people were not following the $\mathrm{CAB}$ in particular, and by the end of January 2021, the situation was back to normal, as if there were no pandemics anywhere. While the rate of vaccination was slowly taking pace, the majority population believed that the vaccination may be necessary later, leading to the vaccine hesitancy.

The second wave which started in the last quarter of March 2021 and spreader much faster than the first wave, is believed to be fueled by the additional strains of the coronavirus, as stated by many health experts. New coronavirus strains are thought to be more infectious home ground variants found in $61 \%$ of samples of genomes sequenced in many states in India. Even such news was reported by media rapidly, the laxity in the $\mathrm{CAB}$ and preventive measures, coupled with the presence of new variants, has resulted in a nationwide crisis. What caught the attention of the globe was despite the ongoing pandemic, the Indian Government allowed State assembly elections in the Eastern part of the country, which could have been delayed at this point. The prime Minster led Government faced this Critic from the opposition while the "Maha Kumbh Mela" organized at Haridwar attended by lacs of devotees who believed to bathe in a ritual river to pure themselves for their mistakes of past was also allowed by the Government. It was reported by media that about 7 million devotees attended the event and 1700 tested positive for covid-19 over 5 days period because no such social distancing measures or masks were used during the Maha Kumbh Mela by the attendees. Most of the public health agencies tried their best to dispel the myths and supported the campaigns associated with covid-19 vaccines but turned a blind eye and acted as a muted spectator for the election rallies and Maha Kumbh Mela. Following COB during election rallies and Maha Kumbh Mela will never go easy hand in hand, so the best is to follow the no man's rule. What we believe the public health professionals of the country followed in deep agony and pressure.

As India is engulfed in the second wave of covid-19, the current situation is deteriorated by the presence of counterfeit drugs, lack of human resources, medical supplies, and equipment. There are unique scientific, technical, and logistic challenges which we face in covid-19, we need to take definite steps for fights against this pandemic.
\end{abstract}

This is an Open Access (OA) journal, and articles are distributed under the terms of the Creative Commons Attribution-NonCommercial-ShareAlike 4.0 License, which allows others to remix, tweak, and build upon the work non-commercially, as long as appropriate credit is given and the new creations are licensed under the identical terms.

For reprints contact: reprint@ipinnovative.com

\footnotetext{
* Corresponding author.

E-mail address: saleem.900@gmail.com (S. M. Saleem).
}

\section{Background}

Soon after the slow decline in the cases of COVID-19 were reported through media since early December 2020 and efforts to vaccinate the Indian population was started 
on $16^{\text {th }}$ January 2021. A ray of hope came as people again starting their livelihoods, roads looked busy again, playgrounds were again full of children and one thing common to all was COVID appropriate behavior (CAB). While the Government was allowing all other activities with the option to follow the CAB keeping a blind eye to whether or not someone follows it. The immediate consequence of this laxity was that people were not following the $C A B$ in particular, and by the end of January 2021, the situation was back to normal, as if there were no pandemic anywhere. While the rate of vaccination was slowly taking pace, the majority population believed that the vaccination may be necessary later, leading to the vaccine hesitancy.

The second wave which started in the last quarter of March 2021 and spreader much faster than the first wave, is believed to be fueled by the additional strains of the coronavirus, as stated by many health experts. New coronavirus strains are thought to be more infectious home ground variants found in $61 \%$ of samples of genomes sequenced in many states in India. ${ }^{1}$ Even such news was reported by media rapidly, the laxity in the $\mathrm{CAB}$ and preventive measures, coupled with the presence of new variants, has resulted in a nationwide crisis. It has reached so much that every 24 hours approximately 4000 people die and as on $6^{\text {th }}$ May 20213,980 people lost battle to this deadly disease, taking the national death toll to 230,168 as per the Indian Health ministry Health Statistics ${ }^{2}$ India received praises from the World for managing the COVID19 pandemic as stated by World Health Organization $(\mathrm{WHO})^{2}$, so where did India lose track and regressed towards a volcanic crisis?

What caught the attention of the globe was despite the ongoing pandemic, the Indian Government allowed State assembly elections in the Eastern part of the country, which could have been delayed at this point. The prime Minster led Government faced this Critic from the opposition while the "Maha Kumbh Mela" organized at Haridwar attended by lacs of devotees who believed to bathe in a ritual river to pure themselves for their mistakes of past was also allowed by the Government. ${ }^{3}$ It was reported by media that about 7 million devotees attended the event and 1700 tested positive for covid-19 over 5 days period because no such social distancing measures or masks were used during the Maha Kumbh Mela by the attendees ${ }^{4}$ With a massive second wave of COVID-19 gripping in and sweeping through India, India was about to chart and report the highest number of cases all over the globe in the coming days. Most of the public health agencies tried their best to dispel the myths and supported the campaigns associated with covid-19 vaccines but turned a blind eye and acted as a muted spectator for the election rally's and Maha Kumbh Mela. Following COB during election rallies and Maha Kumbh Mela will never go easy hand in hand, so the best is to follow the no man's rule. What we believe the public health professionals of the country followed in deep agony and pressure.

The vaccine hesitancy has been there in the Indian population since the origin of the term "vaccine" itself, and it would rather be appropriate to term the Indian population less literate in terms of health literacy. ${ }^{5}$ The capability of India to manufacture a vaccine against COVID-19 gave many Indians a sense of pseudo-vaccine nationalism so they got a belief that they can delay the vaccine and get it at a later date or they can achieve herd immunity than any other country in the world. More of infodemic were spread against vaccinations on social media which led to compliance in CAB. Social media was flooded with messages like vaccinations may not offer complete protection against infection, or increased susceptibility to infection after vaccination, etc. Such messages were quickly shared by people with friends and family in groups, causing more havoc and hesitancy.

As of now, many states are reporting a shortage of hospital beds, oxygen supplies, medicines, even spaces in crematoriums and morgues. ${ }^{6}$ The fact is that India is facing a strong, rapidly rising second wave. The States and the Central Government have placed informed, wellcoordinated, and de-centralized policy measures to halt the ongoing wave. Countries like the United States (US), United Kingdom (UK), Saudi Arabia (KSA), and Pakistan have stepped forward and have offered a helping hand to India to help in this bad time. The US has offered to increased supplies of raw materials for vaccine production, UK offered supplies for medical equipment and medicines, KSA for liquid oxygen, and Pakistan for Ambulances and manpower. As India is engulfed in the second wave of covid-19, the current situation is deteriorated by the presence of counterfeit drugs. The people have rushed to the black market to buy drugs for treatment which has even worsen the problem. Fake vials of a drugs used to treat a covid-19 patient whose actual market cost is rupees 2000 is being sold in the black market at a cost of $35000 .{ }^{7}$ There are unique scientific, technical, and logistic challenges which we face in covid-19, we need take definite steps for fights against this pandemic.

Few recommendations we can suggest,

Stringent participation is needed from the state government's authorities backed by the central government for fighting against this pandemic. WHO should also issue advisories and directories to specific countries where such types of religious gatherings are occurring worldwide? Can India again rise to the challenge of COVID-19 Second Wave?

\section{Source of Funding}

None 


\section{Conflict of Interest}

None

\section{Acknowledgement}

All the COVID Warriors who laid their life in the service of their duty all over the world

\section{References}

1. India Covid second wave: How and why India's Covid situation turned grimmer than ever before I India News - Times of India Internet. cited 2021 Apr 21. Available from: https://timesofindia.indiatimes.com/indi a/why-is-indias-second-covid-wave-way-more-severe-than-first/article show/82102250.cms.

2. COVID-19: WHO Chief Tedros Adhanom Ghebreyesus Praises India's Decisive Action, Resolve To End Virus Internet. cited 2021 Apr 26. Available from: https://www.ndtv.com/india-news/covid-19-whochief-tedros-adhanom-ghebreyesus-praises-indias-decisive-actionresolve-to-end-virus-2347816.

3. Baranwal A, Anand A, Singh R, Deka M, Paul A, Borgohain S. Managing the earth's biggest mass gathering event and wash conditions: Maha kumbh mela (India). PLoS Curr. 2015;7.

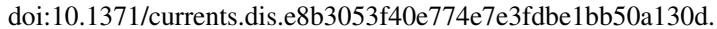

4. Coronavirus | Over 1,700 test positive for COVID-19 in Kumbh Mela over 5-day period - The Hindu Internet. cited 2021 May 7. Available from: https://www.thehindu.com/news/national/coronavirus-over1700-test-positive-for-covid-19-in-kumbh-mela-over-5-day-period/ article34325844.ece.

5. Bhattacharya S. Importance of effective communication during COVID - 19 Infodemic" Are we prepared enough ? A reality check! J Fam Med Prim care. 2021;10(2):1068-71. doi:10.4103/jtmpc.jfmpc_2072_20.

6. How is this second wave different from the first? I Healthing.ca Internet. cited 2021 Apr 26. Available from: https://scroll.in/article/992165/areyounger-people-at-greater-risk-in-indias-second-wave-of-covid- 19 .

7. Covid crisis boosts India's trade in fake medicines / Financial Times Internet. cited 2021 May 7. Available from: https://www.ft.com/ content/1bb3c839-d796-46f8-a2cd-519122a5908c.

\section{Author biography}

Sheikh Mohd Saleem, Public Health Consultant, J\&K, India

Cite this article: Saleem SM. Unfolding the COVID-19 second wave in India. J Community Health Manag 2021;8(3):97-99. 